\title{
Behind the Scenes of COVID-19: The "Hidden Pandemic" of Anti-Asian Racism
}

\author{
Brooke MacNab ${ }^{1}$ \\ bamacnab@gmail.com
}

\begin{abstract}
Alongside COVID-19 came a renewed onslaught of xenophobia and anti-Asian racism, marking people who are or appear to be Chinese as a target for hate-fuelled verbal and physical assaults, some resulting in serious injury or proving fatal for the victims. Using news articles published in Canada to collect data, this research explores the impact of anti-Asian racism within Canada. The findings from this research suggest an uptick in activism throughout the COVID-19 pandemic. Roughly a year after the pandemic, social movements and organizations focused on supporting those with lived experiences of anti-Asian racism and tracking and preventing anti-Asian racism have garnered large followings and support. The resurgence of anti-Asian racism due to the fear associated with COVID-19 is a testament to how we can and should do better in the future to act collectively against racism and xenophobia, by understanding why and how it emerges in order to prevent it.
\end{abstract}

Keywords: Anti-Asian racism; antiracism; allyship; Pacific and Asian studies; xenophobia

\footnotetext{
${ }^{1}$ I would like to say thank you very much to Dr. Andrew Marton for his supervision on this project as part of the Jamie Cassels Undergraduate Research Award, and to the many professors I have had throughout my university degree who have supported my studies and inspired my desire to learn and see the world through a different lens. In no particular order: Andrew Marton, Jun Tian, Angie Chau, and Ben Pin-Yun Wang. 感谢您的支持。
} 


\section{Behind the Scenes of COVID-19: The "Hidden Pandemic" of Anti-Asian Racism}

Wuhan, China. For some, this is the beautiful and bustling provincial capital of Hubei along the shores of the Yangtze River. However, for many around the globe this information has become background noise to another label given to the city, when it was marked as the centre of an outbreak of novel coronavirus by the World Health Organization (WHO), where the label of outbreak implies the "violent start of something unwelcome" (French \& Monahan, 2020, p. 2). And indeed, it was the start of many unwelcome events as COVID-19 has exposed the proverbial cracks within society that exist through social injustices (Scambler, 2020, p. 141) and aggravated pre-existing social inequalities (Jacobson, 2020, as cited in Roberto et al., 2020, p. 365). With the arrival of this new viral respiratory infection, known colloquially as COVID-19, came a renewed onslaught of xenophobia ${ }^{2}$ and anti-Asian racism, that perhaps never really went away in the first place (Abiden \& Zeng, 2020; Ho, 2021).

The xenophobia and racism that have followed in the wake of COVID-19 have impacted the lives of many, marking those "who appear[s] East Asian ... [or] anyone who can be perceived and mistaken to be Chinese" as targets for hate-fuelled verbal and physical assaults, some resulting in serious injury or proving fatal for the victims (Ho, 2021, p. 149). In the midst of such hate, "[the] body becomes a moving target, a target because it can move" (Ritchie, 2020, as cited in French \& Monahan, 2020, p. 5). As Ho (2021) states, "we are all in danger of being victims of violence, verbal or physical, through the flattening of ethnic distinctions in favor of racist and xenophobic ideologies and attacks" (p. 149). These words echo the statement made by holocaust survivor Reverend Martin Niemöller:

[First] they arrested the Communists - but I was not a Communist so I did nothing. Then they came for the Social Democrats - but I was not a Social Democrat, so I did nothing. Then they arrested the Trade Unionists - and I did nothing, because I was not one. And they came for the Jews, and then the Catholics, but I was neither a Jew nor a Catholic and I did nothing. At last they came and arrested me - and there was no one left to do anything about it. (Bartlett, 1980, as cited in Bishop, 2015, p. 10)

Niemöller's words capture how xenophobic ideologies eventually come to harm everyone and anyone, regardless of if you were the initial target or not. This solution this quote points towards is that in order to put a halt to xenophobic actions, one must take action right from the beginning in order to fight collectively for social justice.

It would be remiss of me to not acknowledge my own positionality as a White woman of European descent when discussing this specific topic about communities that have been marginalized by the influence of White supremacy. Colonialism is defined as "a practice of domination, which involves the subjugation of one people to another" (Stanford Encyclopedia of Philosophy, 2017, para. 1). As a White settler in Canada, I inherently benefit from settler colonialism, systemic racism, and oppression enacted and upheld by White supremacy. In my actions to be anti-racist and an ally, I recognize, as put succinctly by Bishop (2015), that I am

one piece in a massive, complex system, part of a people and a history. I have some advantages that I can offer to this struggle - some people will hear me who might not hear

\footnotetext{
${ }^{2}$ Xenophobia is defined as the "fear and hatred of strangers or foreigners or of anything that is strange or foreign" (Merriam-Webster, n.d.).
} 
a racialized person say the same thing; I can take risks with fewer or less serious

repercussions. (p. 11)

As a white woman writing on the topic of anti-Asian racism, my aim is to present this information to a wide range of audiences using an academic lens. As an ally, I am using this paper to uplift the voices of those who have been marginalized by society, while ultimately recognizing that "the shape and direction of the struggle does not belong to me" (Bishop, 2015, p. 11).

\section{Statement of Purpose}

The purpose of this research paper is to showcase how an issue that is medical in nature (as the novel coronavirus is a respiratory illness), became a social issue and political issue (in the form of anti-Asian racism) in Canada over a relatively short period. A secondary aim of this paper is to explore the lasting impact of colonialism through the creation of the Chinese "other" that is perpetuated by anti-Asian racism. Reny and Barreto (2020) point out an area of further research as examining the impact that anti-Asian xenophobia has had on people of "Asian" appearance (p. 19). This paper seeks to fill a gap in the literature, as the literature review conducted prior to the research yielded few articles with Canadian contexts, despite Canada's large Asian population. For example, immigrants from Asia represent $48.1 \%$ of Canada's total immigrant population, and from 2011 to 2016 immigrants from Asia represented 61.8\% of total immigrants to Canada (Statistics Canada, 2017).

As such, this paper will produce a timeline of events in Canada by comparing a sample of news articles published during the beginning phase of the pandemic (January to March 2020), to a similar sized sample roughly a year later (from February 24, 2021 to March 5, 2021). This research was conducted using thematic analysis, a qualitative method chosen in order to provide a rich, detailed account. The data that was analyzed was taken from a thematic analysis of news articles published on events taking place in Canada from the Nexus Uni database. Themes were created in order to amplify the impact of anti-Asian xenophobia on physical safety, in addition to "mental health [and] perceptions of belonging" (Reny \& Barreto, 2020, p. 19). The themes were created inductively, where the themes are derived from the data rather than established prior using an existing theory.

\section{Literature Review}

\section{Anti-Asian Racism}

Through the emergence of the novel coronavirus, notions about threat from racial groups have also emerged, due "to deeper cultural narratives of racial contagion" (French \& Monahan, 2020, p. 6). For example, the scapegoat of Asian people spreading the virus "[resonates] more in popular imagination than travelling businessmen who brought COVID home with them" (Scambler, 2020, p. 146). Additionally, research conducted by Reny and Barreto (2020) suggests that in the beginning stages of the pandemic in early 2020, "anti-Asian attitudes" became attached to thoughts and actions about COVID-19 (p. 1). 
Xenophobia and anti-Asian racism are not new concepts in Canada; rather, they have slipped into relative abeyance, ${ }^{3}$ to re-emerge with a vengeance amid COVID-19. Previous historical events that featured "the Asian-enemy" (Ho, 2021, p. 152) can be found in Canada with Japanese internment during the Second World War (Roberto et al., 2020, p. 364), the Chinese Head Tax, and the Komagata Maru incident. These events are rooted in "centuries of European imperialism and conquest," due to the label of "other" given to people from the Pacific and Asia region during this time (Said, 1978, as cited in Roberto et al., 2020, p. 364).

Xenophobia has a blanket impact upon society, not only affecting those of Chinese descent, but also other people from different nationalities as they are targeted for their "Asian" appearance, for example, "a Vietnamese cultural center was vandalized . . . two Korean men were stabbed . . . and Inuit people have been spat on and told to go back to their "home country" (Richardson, 2020 as cited in Roberto et al., 2020, p. 37). These events exemplify how ethnic distinctions can be flattened by "racist and xenophobic ideologies" that spur people to attack others who are perceived to be "other" based on appearance (Ho, 2021, p. 149). The targeting of Inuit people in particular showcases the flattening of ethnic distinctions in order to persecute those with a "different" (non-white) appearance, as Inuit people have lived within Canada since time immemorial. ${ }^{4}$

\section{Orientalism, Colonialism, and Othering}

In Orientalism by Edward Said, othering is described as the process of creating " "orientalist' fantasies" that are used to construct a system to dominate "consciously or unconsciously ... over the Orient" (Macfie, 2002, p. 8) or assert "the positional superiority of the [White] West" (Kleisath, 2014, p. 148). In order to undermine other cultures and civilizations, Orientalist notions establish that Asia is "an unchanging monolith," where people with Asian heritage are diminished into one singular ethnic label: "Asian" (Said, 1978, as cited in Kleisath, 2014, p. 150).

Oppression and xenophobia are upheld by White supremacy, which "[are] in the air we breathe and the water we drink" (Ho, 2021, p. 151). In Discourse on Colonialism, Césaire (2000) discusses how Europe becoming a colonial power "literally" created the Third World, specifically by creating "the [White European] colonizer's sense of superiority, their sense of mission as the world's civilizers," which all balances on the precipice of one crucial step: "turning the Other into a barbarian" (p. 9). If the "Third World," as it has been conceptualized by the colonizers in the halls of White history, has a culture or a civilization, it must be deliberately destroyed in order for the colonizer's purpose, "domination of the rest of the world," to be achieved (Césaire, 2000, p. 9). Furthermore, statements such as "[the] only history is White ... [the] only ethnography is White," show the implicit bias present in colonial thought-based studies, where "the West" studied "the East" but not vice versa (Césaire, 2000, p. 71).

Over time, the process of othering has become broadly defined as a method for "discrimination and exclusion used against individuals on the basis of their belonging to

\footnotetext{
${ }^{3}$ Relative is used to acknowledge the acts of anti-Asian racism in everyday life prior to COVID-19. that slipped "under the radar" due to their commonplace presence in a society that upholds White supremacy, for example, in generalizing racial stereotypes.

4 “Time so long past as to be indefinite in history or tradition” (Merriam-Webster, n.d.)
} 
marginalized groups" (Krumer-Nevo \& Sidi, 2012, p. 300). Othering creates the notion of competitive oppressions, where in order to get ahead or protect oneself, others are pushed down. Bishop (2015) states that we have learned to "despise and distrust those who are different from us," and by pushing others down based on these differences, "we are reinforcing each other's oppression and eventually our own" (pp. 8-9). Scambler (2020) states that the circumstances of COVID-19 have placed a new emphasis on differences, where new "visible exclusionary practices" have been created that focus "on race or ethnicity" (p. 146).

\section{Methodology}

Present day society is mediated by people using technology to access information, such as news media, where relationships are forged alongside prejudices (Silverstone \& Georgiou, 2005, as cited in Hodgetts \& Chamberlain, 2014, p. 380). Due to the central position of media in everyday life, it is an important area to study, as news media "constructs' events and relationships between groups of people ... [calling] attention to some aspects of reality while obscuring other elements" (Entman, 1993, as cited in Hodgetts \& Chamberlain, 2014, p. 381). This paper uses components of the text-in-context approach by Hodgetts and Chamberlain (2014) in order to recognize that news media are created in the world that they are derived from, and thus are "situated in social relations and cultural practices that lie beyond the text," such as racism and other biases (p. 383). Furthermore, the perspectives shared in news media compared to those "whose views are restrained ... reveals much about wider power relations in a society" (Couldry \& Curran, 2002 as cited in Hodgetts \& Chamberlain, 2014, pp. 380-381). Thus, new media can contribute to the further marginalization of populations by not sharing their thoughts and perspectives.

The purpose of this paper is to show, through a thematic analysis of news articles, how anti-Asian racism in relation to COVID-19 perpetuates exclusionary practices based upon race (Scambler, 2020, p. 146), which also contributes to the creation of the "other" in society, a contrast to the "pervasiveness of white normativity, white privilege, and white supremacy" (Ho, 2021, p. 152). The thematic analysis consists of data derived from a sampling of news articles on the Nexus Uni database that are about events taking place in North America. Articles were collected using the specific keyword "anti-Asian," with filters for date range (January 1, 2020 to March 29, 2020), and selecting "Canada" under the location filter. A secondary, contrasting sample was collected using the same keyword (anti-Asian) with the following filters: news, last 30 days (February 3, 2021 to March 5, 2021), organized newest to oldest.

The articles were imported into QDA Miner Lite by copying and pasting the article from Nexus Uni into QDA Miner Lite to make a transcript. The transcript was then given an initial code according to the month the article was published, then coded thematically. The search for articles yielded many that were duplicates of the same story but posted on different news platforms. Thus, duplicate articles were not counted toward this research or given a complete thematic analysis; rather, they were given the code of "duplicate," and original articles were given the code "original." In the case an article was found only once, it was still given the code of "original." Only those articles that were coded as "original" were analyzed. Ryan and Benard (2013) state that "[t]he more the same concept occurs in a text, the more likely it is a theme"; thus, themes were identified through repetition (p. 89). These themes were then refined using Neale's (2016) process of iterative categorization, which involves three activities: data reduction through simplification, data display, and lastly, "interpreting the data" (p. 1098). 


\section{Findings}

A total of 76 articles were collected and analyzed for the purposes of this study. From January 1, 2020 to March 30, 2020, the purposive sampling of news articles yielded 38 articles. In order to provide an equal size comparison, 38 articles were sampled a year later. The 38 articles from the contrasting period came from the time period of February 24, 2021 to March 5, 2021. Overall, from these 76 articles two main themes emerged: the spread of fear and the rise of hope.

\section{Theme 1: The Spread of Fear}

The first theme, the spread of fear, was generated from news media articles discussing instances of anti-Asian racism, misinformation, and physical and/or verbal violence and was separated into three subsections: presence of hate crimes within big cities, linkages to past history, and types of actions and impacts.

\section{Presence in Big Cities}

An unnamed speaker stated, "I have sometimes faced racism [in Canada] but the experience of these past two to three months has been terrible" (Chung, 2021, para. 8). This quote is corroborated by crime statistics. Anti-Asian hate crimes in Vancouver from 2019-2020 rose by 717\% (Docto, 2021, para. 2), where British Columbia was found to be "at the top of the list for most reported anti-Asian incidents per capita," in comparison to sprawling metropolitan provinces such as Ontario (para. 3). Organizations such as The Chinese Canadian National Council - For Social Justice (CCNC-SJ) have compiled 700 reports of anti-Asian hate across Canada (Chung, 2021, para. 10). In Montréal, 30 crimes with Asian victims occurred between December 2020 and March 2020, where " 22 were considered 'heinous crimes' and eight were recorded as 'hate crimes" (Haines, 2021, para. 2). One article states that it is important to understand that deterrence to commit a crime in terms of sentencing is low, as "hate crimes are difficult to prosecute because many incidents aren't viewed as crimes" (Chung, 2021, para. 13).

\section{Historical Linkages}

Some people are targets of racism not because they are Chinese, but due to their "Asianlooking" appearance: "attack victims may not be from areas where Covid-19 originated . . . [and] the rise of attacks against 'Asian-looking people' is deeply rooted in the historical discrimination against Chinese and Asians in Western cultures and societies" (Lau, 2020, para. 4). While COVID19 has to some extent exacerbated anti-Asian racism, social justice advocate Avvy Go says that anti-Asian racism has always existed and "COVID-19 really shines a light on the depth and scope of anti-Asian racism in Canada" (Docto, 2021, para. 1). The President of the Greater Vancouver Japanese-Canadian Citizens Association, Judy Hanazawa states, "It's not surprising that in times of crisis, [racism] surfaces" (Docto, 2021, para. 4). This idea that current racism against Asians is caused by historical linkages outside of fear of COVID-19 is echoed in another interview, where respondent Frank Ye states that "just like the spread of SARS, [COVID-19] has been used to bring back a lot of anti-Chinese, anti-Asian tropes and racist stereotypes that really date back throughout centuries in Canada's history" (Harris, 2020, para. 8).

Past events in history demonstrate that COVID-19 is not the only time when fear of disease and "general xenophobia" have coalesced into "outbreaks of anti-Asian racism .... prejudice 
against Asian communities has been a staple feature . . . since the first Chinese workers arrived in the mid-19th century" (Larsson, 2020, para. 3). Larsson (2020) states that when Chinese immigrants came to Canada to become workers on the Canada Pacific Railway, they were "indispensable workers . . . working at minimal pay compared to their white counterparts," and because workers could be paid less and "exploited for cheap labour was exactly why Canada's first prime minister . . . encouraged Chinese immigration" (para. 11). However, when the railway was finished but the immigrants remained, they were labelled by a White spokesperson "as 'dangerous to the white,' living in 'most unhealthy conditions' with a 'standard of morality immeasurably below ours"" (Larsson, 2020, para. 6).

These racist remarks were combined with petitions for the Canadian government to remove Chinese immigrants. For example, in 1880 "the Anti-Chinese Association of Victoria submitted a petition to Ottawa against 'the terrible evil of Mongolian usurpation' in Canada" (Larsson, 2020, para. 15). Four years later in 1884, the Royal Commission on Chinese Immigration was created "to determine the impact of Chinese presence in Canada" and hearings were conducted in order "to gather evidence from witnesses - [out of] over fifty people from among from the police, government, physicians and the public .... Only two of the witnesses were Chinese" (Larsson, 2020, para. 16). The report reveals how underlying racism and prejudice have long formed the foundation of anti-Asian rhetoric, with the commission reporting that "Chinese quarters are the filthiest and most disgusting places in Victoria, overcrowded hotbeds of disease and vice, disseminating fever and polluting the air all around," despite knowing that these conditions were the result of poverty rather than based upon the ethnicity of those living in the location (Larsson, 2020, para. 19).

\section{Actions and Impacts}

Anti-Asian racism is present in different forms: in person and online. On the internet, comments and posts have been created that call Chinese people "dirty" or "disease-ridden"” (Harris, 2020, para. 7) and emails have been sent in response to those speaking out against antiAsian hate (Docto, 2021). Alongside waves of COVID-19, there has been an accompanying "spike in racist terms, memes and news articles targeting Asian communities" (Larsson, 2020, para. 2). This spike includes use of the slurs "Wuhan virus" or "China virus" popularized by right-leaning political figures, which has "done tremendous damage to Canada's Chinese community" (BrownJohn, 2021, para. 4).

Brown-John (2021) states that data from an Angus Reid poll with Chinese ethnicity participants revealed that "50 per cent had been called names or insulted and blamed for the virus ... [and another] 43 per cent had been personally threatened, physically attacked or intimidated" (para. 13). An example of the variety of anti-Asian racism is showcased in the following:

[Asian people] report being spit on, yelled at, even threatened in the streets. There has been a recent stabbing in Montréal and increased violent targeting of Asian businesses ... [there were] over 650 racist attacks last week according to the Asian Pacific Policy and Planning Council (Larsson, 2020, para. 2).

In Vancouver, "[Judy] Hanazawa remembers an incident at a park last May with her friends where a white man told them to 'go back to China' ... [and] walking on the street and someone spitting right in front of her face" (Docto, 2021, para. 8). In the streets of Toronto, "one of the most ethnically diverse cities in the world," a PhD student was yelled at, called slurs, and pushed while on campus and within the city (Lau, 2020, para. 5). These experiences have resulted in the victim 
having difficulty focusing on schoolwork (Lau, 2020, para. 5). In combination with fears of catching COVID-19, the fear of being a victim of an anti-Asian hate crime has had an overall "detrimental impact on mental health" (Docto, 2021, para. 8).

\section{Theme 2: The Rise of Hope}

The second theme, the rise of hope, was generated from the mention of activism, allyship, and solidarity within news articles. This theme is divided into the following subsections: the rise of reporting (increase in number of articles shown in findings), and the creation of community-led organizations and educational resources.

\section{Rise of Reporting}

Despite calls to action in the early stage of the pandemic, those reporting crimes were told "without concrete data ... [their] story wasn't newsworthy. At the time, Montréal police claimed there was no uptick in hate crimes against Asians. . . W Without statistics, it meant these incidents didn't officially exist" (Chung, 2021, para. 1-2). In a three month period in early 2020, 38 articles were found, whereas in early 2021, it only took ten days to sample the same 38 number of articles. The disproportionate number of articles for these two time periods indicates a rise in reporting over time.

In the early stages of the pandemic, health officials such as Theresa Tam used their status as leaders within the community to provide a platform to raise conversation about anti-Asian hate. Harris (2020) states that Tam used Twitter to post that "the growing number of reports of racist acts and comments on social media directed at people of Chinese and Asian descent . . . [are] unacceptable and very hurtful" (para. 2). Furthermore, racist and xenophobic values promote othering and exclusion, "creating a divide of us versus them" (Harris, 2020, para. 3). Government officials, such as Toronto Mayor John Tory, also joined the discussion, stating that "“shunning' Chinese Canadians or avoiding their businesses ... [is] immoral and harmful. This type of thinking is wrong ... [and] entirely inconsistent with the advice of our health care professionals" (Harris, 2020, para. 10-11). Academic discussions also began to enter into news media forums. One article includes an interview with Cary $\mathrm{Wu}$, an academic who is conducting research "on whether rising 'anti-Asian-looking' sentiment is a result of the coronavirus outbreak specifically or rather just part of a wider strand of xenophobia in Western society" (Lau. 2020, para. 3).

\section{Creation of Organizations and Educational Resources}

The Chinatown Security Service neighbourhood patrol in Montréal was created by Jimmy Chan in order to combat increased anti-Asian sentiments (Haines, 2021) and is only one example of such organizations. In an article, Chan states, "We have our right, our space and a right to speak" (Haines, 2021, para. 17). In addition to documenting the creation of organizations, the findings revealed an upsurge in the creation of educational resources to learn more about anti-Asian hate, such as the Chinese Canadian National Council — For Social Justice (CCNS-SJ) and Project 1907, which have collaborated to create resources to stop Asian hate. "In April, two concerned Asian Canadians in Vancouver launched Project 1907, horrified by the racism they experienced and witnessed in Chinatown .... [CCNC-SJ] started a website to report and track incidents across 
Canada. The groups decided to pool their incident data together. To date, they have collected more than 700 anti-Asian incidents" (Chung, 2021, para. 11).

Other educational resources include a booklet titled Challenging Racist British Columbia (read for free at challengeracistbc.ca), created by the Canadian Centre for Policy Alternatives and researchers from the University of Victoria. Ducklow (2021) states that this booklet looks at the "anti-Asian immigration laws that led to B.C. having a white majority and the attempted ethnic cleansing of Japanese Canadians" (para. 4) and seeks to disprove "the narrative "that Canada is exempt from white supremacy and racist nation state formations"" (para. 6) in order to "help pierce the silences that too often have let racism grow in our communities, corporations and governments" (para. 3). This booklet also acts as a resource for "non-racialized people . . who may be engaging with these issues for the first time" to engage with the topic of anti-Asian racism. "Racism and white privilege can seem abstract ... [and] this booklet lays out specific ways policy in B.C. created racial divide and deliberately disadvantaged people of colour" (Ducklow, 2021, para. 7).

These words by Ducklow bring in the concept of allyship. A theme in the articles is the idea anti-Asian racism is not an "Asian only" issue and that acts of allyship are needed: "[it] all boils down to being an ally_learning about the history of anti-Asian racism, listening to the people directly affected by this xenophobia and safely intervening when you witness a racist attack" (Docto, 2021, para. 18). Furthermore, knowledge should be generated on building "“effective measures' to fight xenophobia," such as efforts to promote diversity in both work and school environments by creating "inclusive environments and encouraging interracial interactions; and building up programmes that help students to cope with the psychological effects of racial attacks" (Lau, 2020, para. 7). The creation of knowledge-based policy is echoed in an article by interviewee Adam Olsen: "If you don't ask the questions, you don't collect the data, then you don't know and you become blind to the nuances of the way policies are affecting outcomes for different people" (DeRosa, 2021, para. 20).

\section{Discussion}

Ho (2021) states that Asian Pacific studies has shifted to look at the transnational, thinking about how "immigration, settler-colonialism, racism, and xenophobia have and continue to impact the lives of various Asians living outside of their natal Asian lands . . . in terms of multiple generations or recent relocation" (pp. 148-149). This research studies the impact of anti-Asian racism in Canada and showcases how racism within the past has been carried into the present day. This research reaffirms and amplifies that anti-Asian racism is a social issue in need of a solution. Furthermore, the work toward a solution is pressing due to the impact on the well-being of those who have been victimized by racist and xenophobic acts. The news articles collected for this research showcase the negative impact of anti-Asian racism on feelings of physical safety and well-being, evident through astronomically heightened crime statistics, such as the $717 \%$ rise in attacks against Asians in Vancouver (Chung 2021).

Additionally, the media analysis used in this research to collect data shows that there is still inherent racism and exclusion of stories when they are told by groups that have been marginalized by society. This exclusion is exemplified by the increase of findings over time, not because they did not exist, but rather that they were underreported; not reported at all; or told that their stories were not "newsworthy"- thus "these incidents didn't officially exist" (Chung, 2021, para. 1-2). 
This is similar to Césaire's (2000) claim that the only history is White history (p. 71), and in order to create "newsworthy" information there needs to be concrete data, which is often hard to capture, and it is also hard to prosecute those who commit anti-Asian hate crimes (Chung, 2021, para. 13). These two factors further contribute to the marginalization of "Asian-appearing" people, typically members from "non-White" racial groups.

Despite this continued impact of colonialism, there is room for hope in the answer to "what can be done moving forward in order to prevent anti-Asian racism?' The answer is in the findings: collective efforts to educate, become allies, and show solidarity (Docto, 2021). There has been a turn toward a hopeful future where anti-Asian racism is shunted; however, it has been a slow process. The theme of calling in allies through encouraging education was prevalent, with authors of the articles and interviewees recommending resources such as CCNS-SJ and Project 1907.

\section{Education and Activism}

At the time of writing this article, there has been an uptick in activism and more conversations are starting to occur. But is it enough? Occurrences of anti-Asian racism continue, whether in small-scale forms, such as anti-Asian comments, or large-scale events, such as the death of eight people in Atlanta on March 16, 2020. This has led Canadian government officials to "recondemn" anti-Asian racism and "urge the government to take further action to tackle hate crimes" (Jackson, 2021, para. 3). The creation of educational resources has had a heavy presence on social media (such as Instagram), and the resources are being used in the technology-mediated world of COVID-19 to provide education on anti-Asian racism. Organizations such as @ dearasianyouth run an Instagram page and a Twitter feed that provide accessible infographics for followers to learn more, and to help and become an ally. ${ }^{5}$ Furthermore, organizations such as Hollaback! and AAJC have teamed together to provide free bystander intervention training (centred around stopping xenophobic harassment) and conflict de-escalation training to anyone around the globe over Zoom. Over 45,000 people have attended these training sessions since the shooting in Atlanta on March 16, 2020 (Hollaback!, personal communication, April 1, 2021).

Training provided by Hollaback! And AAJC offers five methods of intervention (5Ds): Distract, Delegate, Document, Delay, and Direct (Hollaback!, n.d.). Bystander intervention was pointed out as a solution in the findings (Docto, 2021), and Hollaback! (n.d.) resources iterate the importance of being an active bystander with the statement: "What's worse than being targeted with harassment because of your race, sex, religion, color, gender, size, orientation, disability, age, or origin? Being targeted while surrounded by bystanders who see what is happening, but then do nothing. It doesn't have to be that way" (para. 2-3).

\section{Limitations and Areas for Further Study}

In comparison to its presence at the beginning of the pandemic, anti-Asian racism has been recognized as a social problem by many and is garnering a large following in public discourse. However, this labelling of anti-Asian racism as a "social problem" alone is not enough; action is needed, especially as questions on how to solve this social problem are raised. However, this paper was written from a White woman's perspective, and as such the limitations of this study rest in my

\footnotetext{
5 @dearasianyouth instagram post. Source: https://www.instagram.com/p/CMiXpP D7-O/?igshid=1bcjrn9rbs6js
} 
own positionality. My own worldview and implicit biases dictate what I see and mark as important, such as the themes of this paper.

An area of further study would be to look at the influence of social media (WeChat, Instagram, Facebook, Twitter, etc.) on anti-Asian racism, an area only briefly touched upon in Abidin and Zeng (2020)'s study of community discussions on Facebook. As the current study relied on the Nexus Uni database, which uses "traditional" sources like online news websites for information, the information and news created by community-led organizations on social media platforms like Instagram or Twitter was not captured.

\section{Conclusion}

The increased racist xenophobia associated with COVID-19 that has led to an increase of anti-Asian racism is a testament to how we can and should do better in future to work collectively against racism and xenophobia. This work can be done by understanding why and how anti-Asian racism emerges in society and what can be done to prevent it and to combat racism in general. As Bishop (2015) states, "[No] one oppression can be ended without ending all" (p. 9); thus, steps to ending anti-Asian racism will ultimately benefit society as a whole. This research addresses the gap in academic literature about anti-Asian racism in the Canadian context and provides a brief snapshot of events that capture the multi-dimensional impact of COVID-19 upon socio-political contexts. The findings from this research suggest an uptick in activism throughout the COVID-19 pandemic. Roughly a year after the pandemic, social movements and organizations focused on supporting those with lived experiences of anti-Asian racism and tracking and preventing antiAsian racism have garnered large followings and support.

However, this research is limited by my positionality. As a white ally, my work is not done; however, as a white ally it is also my time to effectively "sit down, shut up, and listen" (Bishop, 2015 , p. 104). This research is only the introductory chapter to this pressing social issue, and there is still much work to be done. As Ho (2021) states, "the work of anti-racism is not easy. But it is open and available to us all. The only requirement for being an anti-racism educator and ally is the will to make this choice" (p. 155). 


\section{References}

Abidin, C., \& Zeng, J. (2020). Feeling Asian together: Coping with \#COVIDRacism on subtle Asian traits. Social Media + Society, 1(1), 1-5. https://doi.org/10.1177/2056305120948223

Bishop, A. (2015). How to be an Ally: Breaking the cycle of oppression in people (3rd edition). Fernwood Publishing.

Brown-John, L. (March 5, 2021). Guest column: Ethnic blame game on COVID-19 triggered hate and should cease. Postmedia Breaking News. https://windsorstar.com/opinion/letters/guest-column-ethnic-blame-game-on-covid-19misguided-and-should-cease

Césaire, A. (2000). Discourse on colonialism. Monthly Press Review.

Chung, A. (March 1, 2021). In 2021, Asian Canadians document hate crimes to be believed. Huffington Post. https://www.huffingtonpost.ca/entry/anti-asian-racismcanada_ca_603d08cdc5b682971502118f

DeRosa, K. (February 28, 2021). Community groups question whether anti-racism legislation can change systemic racism in B.C. The Vancouver Sun (British Columbia). https://vancouversun.com/news/local-news/community-groups-question-whether-antiracism-legislation-can-change-systemic-racism-in-b-c

Docto, I. (March 3, 2021). Anti-Asian violence spiked during COVID-19, Here's what you should know. Chatelaine. https://www.chatelaine.com/living/anti-asian-violencecovid-19/

Ducklow, Z. (February 25, 2021). New resource dives into 150 years of racist policy in B.C.. Abbotsford News. https://www.abbynews.com/news/new-resource-dives-into-150years-of-racist-policy-in-b-c/

French, M. \& Monahan, T. (2020). Dis-ease surveillance: How might surveillance studies address COVID-19? Surveillance \& Society, 18(1), 1-11. https:/doi.org/ $10.24908 /$ ss.v18i1.13985

Haines, B. J. (March 3, 2021). Montreal's Asian community sees increase in targeted hate crimes, police say. Global News. https://globalnews.ca/news/7674090/montreal-asian-hate-data-police/

Harris, K. (January 30, 2020). Canada's chief public health officer condemns racist acts linked to coronavirus outbreak. CBC News. https://www.cbc.ca/news/politics/tam-public-health-coronavirus-racism-1.5445713

Ho, J. (2021) Anti-Asian racism, Black lives matter, and COVID-19. Japan Forum, 
33(1), 148-159. https:/doi.org/10.1080/09555803.2020.1821749

Hodgetts, D., \& Chamberlain, K. (2014). Analysing news media. In U. Flick (Eds.), The SAGE handbook of qualitative data analysis (pp. 380-393). SAGE Publications Ltd. https://doi.org/10.4135/9781446282243.n26

Jackson, H. (March 22, 2021). Canadian MPs vote to condemn Atlanta mass shooting, anti-Asian racism. Global News. https://globalnews.ca/news/7712225/mps-condemn-anti-asian-hate/

Kleisath, C. M. (2014). The costume of Shangri-La: Thoughts on white privilege, cultural appropriation, and anti-Asian racism. Journal of Lesbian Studies, 18(2), 142157. https:/doi.org/10.1080/10894160.2014.849164

Krumer-Nevo, M. \& Sidi, M. (2012). Writing against othering. Qualitative Inquiry, 18(4), 299-309. https:/doi.org/10.1177/1077800411433546

Larsson, P. (March 31, 2020). Anti-Asian racism during coronavirus: How the language of disease produces hate and violence. The Conversation - Canada. https://theconversation.com/anti-asian-racism-during-coronavirus-how-the-language-ofdisease-produces-hate-and-violence-134496

Lau, J. (March 26, 2020). Coronavirus sparks a rising tide of xenophobia worldwide. The Times Higher Education Supplement. https://www.timeshighereducation.com/news/coronavirus-sparks-rising-tideofxenophobia-worldwide

Macfie, A. L. (2002). Orientalism. Routledge.

Merriam-Webster. (n.d.). Time immemorial. Retrieved August 28, 2021 from https://www.merriam-webster.com/dictionary/time\%20immemorial

Merriam-Webster. (n.d.). Xenophobia. Retrieved February 23, 2021 from https://www.merriam-webster.com/dictionary/xenophobia

Neale, J. (2016). Iterative categorization (IC): A systematic technique for analysing qualitative data. Addiction, 111(6), 1096-1106. https://doi.org/10.1111/add.13314

Reny, T. T. \& Barreto, M. A. (2020). Xenophobia in the time of pandemic: Othering, anti-Asian attitudes, and COVID-19. Politics, Groups, and Identities, 1(1), 1-25. https:/doi.org/10.1080/21565503.2020.1769693

Roberto, K. J., Johnson, A. F. \& Rauhaus, B. M. (2020). Stigmatization and prejudice during the COVID-19 pandemic. Administrative Theory \& Praxis, 42(3), 364-378. https:/doi.org/10.1080/10841806.2020.1782128 
Ryan, G. W., \& Bernard, H. R. (2003). Techniques to identify themes. Field Methods, 15(1), 85-109. https://doi.org/10.1177/1525822X02239569

Scambler, G. (2020). Covid-19 as a 'breaching experiment': Exposing the fractured society. Health Sociology Review, 29(2), 140-148. https:/doi.org/10.1080/14461242.2020.1784019

Stanford Encyclopedia of Philosophy. (2017, August 29). Colonialism. Retrieved February 23, 2021 from https://plato.stanford.edu/entries/colonialism/

Statistics Canada. (2017). Immigrant population by selected places of birth, admission category and period of immigration, Canada, provinces and territories, census metropolitan areas and areas outside of census metropolitan areas, 2016 Census. Retrieved March 13, 2020 from https://www12.statcan.gc.ca/censusrecensement/2016/dp-pd/dv-vd/imm/index-eng.cfm 